\title{
Women's Health Beliefs Regarding Osteoporosis in Alexandria
}

\author{
Fathia Khamis Kassem, Lecturer \\ Community Health Nursing, Faculty of Nursing, Alexandria University
}

\begin{abstract}
Osteoporosis represents the major public health concern which affects millions of people worldwide. Many genetics and life style factors influence the occurrence of the disease. Heath belief model (HBM) is a well-known instrument to investigate the health beliefs related to osteoporosis. Objective: To assess the health beliefs of women regarding osteoporosis in Alexandria. Settings: The study was carried out in four family health centers in Alexandria. Subjects: The subjects of the study were 260 women aged above forty years who attended the different family health centers clinics for follow up. Tools: Two tools were used for data collection. The first one was a socio-demographic characteristic of the studied women and health status structured interview schedule for the women which assessed their medical, surgical, menstrual history and women history of fracture. The second tool was the Osteoporosis Health Belief Model Scale (OHBS), it was used to measure heath beliefs related to osteoporosis. Results: More than three quarters of the studied women had previous health problems. Hypertension, arthritis, and high cholesterol level were reported by more than two fifths of the women and about one third of them had previous family history of osteoporosis. Moreover, around one third of the studied women had low perceived susceptibility to osteoporosis and more than half had low perceived seriousness to the disease. Conclusion: The findings from this study indicate that osteoporosis related health beliefs and behaviors among the studied women were inadequate. Recommendations: Raise public awareness with respect to osteoporosis including the extent of the problem and means for overcoming it. This could be done through intensification of media, awareness campaigns and community mobilization.
\end{abstract}

Keywords: Osteoporosis, Health belief model, Women and osteoporosis, Prevention of osteoporosis.

\section{Introduction}

Osteoporosis represents the major public health concern worldwide ${ }^{(1)}$. It affects millions of people around the world and its frequency increases by age ${ }^{(2)}$. It is a common skeletal disease characterized by low bone mass and micro architectural deterioration of bone tissues resulting in increased risk for fracture ${ }^{(3)}$. It is termed silent disease because there are often no symptoms until a fragility fracture occurs ${ }^{(4)}$. The most common fracture sites are the spine, wrist, and hip ${ }^{(5)}$. Fracture in older adults decrease their perceived confidence to perform activity of daily living and affect their quality of life ${ }^{(6)}$.
Osteoporosis has become a silent epidemic. By 2020, one in two Americans over age of fifty will have or be at risk for developing Osteoporosis. Approximately ten million Americans have Osteoporosis, of these eight million are women and two million are men ${ }^{(5)}$. In Egypt, it has been calculated that $53.9 \%$ of post-menopausal women have Osteopenia (it is diagnosed when there is reduced mineral content in bone, but not as low as to be consider osteoporosis) and $28.4 \%$ have Osteoporosis but in men $26 \%$ have Osteopenia and $21.9 \%$ have Osteoporosis ${ }^{(7)}$.

Many genetic and life style factors influence osteoporosis. The patients' history of fracture, diet, and life style used to assess risk for the disease and bone mineral 
density (BMD) measurement are used to confirm clinical osteoporosis ${ }^{(6)}$. Women are at two to three times higher risk than men because of the rapid bone loss at menopause due to sharp decline in estrogen production .Insufficient awareness of osteoporosis and related prevention were among the most important reasons for the disease ${ }^{(8)}$.

Osteoporosis is a preventable disease as primary prevention is the most cost effective approach from economic perspectives. Life style modification such as diet, exercise, and smoking are important in preventing or deterring development of the disease and reducing the risk for fracture ${ }^{(9)}$. Health Belief Model (HBM) is a wellknown instrument for investigating beliefs associated with perceived seriousness and perceived susceptibility to disease, benefits, barriers to exercise and calcium intake, and health motivation ${ }^{(3)}$.

The individual should belief that the disease is serious enough, such that he or she is susceptible to it and that the benefits of taking a particular action exceed the barriers $^{(10)}$. Community health nurses are in a unique position to create the community awareness about osteoporosis by conducting health education to children, youth and families about prevention of osteoporosis through healthy life style to promote bone health such as doing regular aerobic exercises, maintain normal body weight, eating calcium rich food and vitamin D supplementation $^{(11,12)}$. Furthermore, community health nurses play a vital role in screening for the disease through their involvement in the assessment of patients at various point of contact within health care system, primary health care settings; chronic outpatient clinics, long term care, and community home care ${ }^{(13)}$.

\section{Aim of the Study}

The aim of the study was to assess the women's health beliefs regarding osteoporosis in Alexandria.

\section{Research Question:}

What are the women's health beliefs regarding osteoporosis in Alexandria?

\section{Materials and Method}

\section{Materials}

Design: A descriptive study design was used to carry out the study.

Settings: Multistage sampling technique was used to select the study settings as follows:

- Two zones out of eight zones of Alexandria were selected randomly namely East and Middle zone.

- Two family health centers from each zone were selected according to the highest attendance rate of the women.

- The total number of family health center were four centers namely Abees 2, Smouha, Moharam Bek, and Al Hadara family health center.

Subjects: According to Epi Info 7 sample size estimation program 260 women out of 1195 (representing the average number of women attending the family health centers during the last six months prior to the study) were included in the study.

By using the equal allocation method, 65 women were selected from each family health center by using convenient sampling technique.

Inclusion criteria: Women above 40 years who were attending the different family health center's clinic for follow-up.

Tools: In order to collect the necessary data for this study, the following tools were used:

Tool I: Women's Socio-demographic Characteristics and Health Status Structured Interview Schedule

This tool was developed by the researcher after reviewing the recent literature to collect necessary data from the selected women. It included the following parts; the first part: women's socio-demographic characteristics (age, marital status, level of 
education, working condition and income), the second part: women's medical and surgical history (history of health problem, received medications, and history of surgeries \& its type), and measuring the present body mass index. The third part: women's menstrual history (age of menarche, history of menstrual disorders, and menopausal history), and the fourth part: women history of previous fracture (type, number and sites).

Tool II: The Osteoporosis Health Belief Model Scale (OHBMS) ${ }^{(14)}$

It was developed by Kim and colleagues (1991) and translated into Arabic by Malak $\mathrm{Z}(2013)^{(13)}$. OHBMS used to measure health beliefs related to osteoporosis. It is a 42-item instrument consisting of seven subscales addressing health beliefs. The subscales address: susceptibility, severity, benefits to exercise, benefits to calcium intake, barriers to exercise, barriers to calcium intake, and health motivation. The format of the scale is 5 point Likert scale included "strongly agree, agree, disagree, strongly disagree and undecided". The score of five is to strongly agree, four to agree, three to undecided, two to disagree and one to strongly disagree. Possible range of 42 to 210 for the total health belief score. A possible range of 6 to 30 for each subscale score. Higher scores for barriers indicate more negative health beliefs, and the rest higher scores indicating positive health beliefs. The overall reliability of the OHBMS based on Cronbach's alpha coefficient for the 42 items was 0.895 .

\section{- Scoring system:}

The Osteoporosis Health Belief Model Scale (OHBMS) Scoring System: Each woman was asked to respond to 42 statements by using a 5point Likert self-rating scale which ranged from (1) strongly disagree to (5) strongly agree. The total OHBMS score ranged from 42 to 210 points, it was divided into seven subscales.

Each subscale score was classified into two categories (low and high) according to the mean score. A possible range of mean was ranged from 6 to 30 for each subscale score. The mean score ranged from 6 to 18.9 was considered low, while the mean score ranged from 19 to 30 was considered high. The higher scores for barriers (Calcium barrier and exercise barrier) indicate more negative health beliefs toward osteoporosis prevention, and the rest higher scores indicating positive healthy beliefs.

\section{Method}

- Approval of the responsible authorities was obtained through official letter from the Faculty of Nursing to the director of Ministry of Health and Population (MOHP) in Alexandria to collect the necessary data from the four selected family health centers.

- After reviewing the recent literature tool I was developed by the researcher. It was validated by juries of five experts in the field of Community Health Nursing. Their suggestions and recommendations were taken into consideration.

- A pilot study was carried out on 26 women in order to ascertain the relevance, clarity and applicability of the tools, test wording of the questions and estimate the time required for the interview. Based on the obtained results, the necessary modifications were done.

- Data were collected by the researcher over a period of six months from September 2015 to February 2016 through interviewing the studied women individually.

\section{Ethical considerations:}

- Informed oral consent was obtained from all women after providing an appropriate explanation about the purpose of the study and nature of the research. 
- The confidentiality and anonymity of individual responses, volunteer participation and right to refuse participating in the study were emphasized to the women.

\section{Statistical Analysis}

- The collected data were coded and analyzed using PC with the Statistical Package for Social Sciences (SPSS version 11.5) and tabulated frequency and percentages were calculated.

- The variables were analyzed using descriptive statistics which included arithmetic mean, standard deviation, percentages and frequencies.

- ANOVA test was used to test the association between variables. the level of significance selected for this study was $p$ value equal to or less than 0.05 .

\section{Results}

Table (1) shows that women's age ranged from 40 to more than 60 years with a mean of $49.27 \pm 8.573$ years. Slightly less than two thirds of the studied women $(65.4 \%)$ were married, slightly more than one third $(35 \%)$ of them have either three or four children with the mean number of children is $3.01 \pm 1.249$. The majority $(95 \%)$ of the women lived in urban areas. Regarding their level of education it was observed that, more than two fifths $(44.2 \%)$ have secondary education and less than one tenth $(9.2 \%)$ were illiterate. Slightly more than half $(53.8 \%)$ were housewives. Finally, more than half $(56.5 \%)$ reported having enough income.

Table (2) portrays that more than three quarters $(79.6 \%)$ of the studied women reported that they have previous history of health problems. Hypertension, arthritis, and high cholesterol level were reported by $45.9 \%, 42.5 \%$, and $41.1 \%$ respectively. DM was reported by $29.5 \%$ of the women, while the minority of them suffered from Gout, lumber disc, and osteoporosis $(2.9 \%, 1.4 \%$, and $1.4 \%$ respectively). Around two fifths $(38.5 \%)$ of the women received medication; diuretics were reported by less than two thirds $(61 \%)$ of the women. Sadly to found that $24 \%$ of the women received corticosteroids, one fifth received hormonal replacement therapy, and $12 \%$ received analgesics as over counter medication.

Moreover, more than one tenth $(13.8 \%)$ of the studied women had previous surgery; $52.8 \%$ had hysterectomy, followed by oophorectomy $38.9 \%$. According to BMI classification of the women it was observed that $31.5 \%$ of the women were obese class I, and $28.8 \%$ were overweight and the minorities were obese class III or underweight ( $4.2 \%, 1.2 \%$ respectively).

Table (3) reveals that the age at menarche of the studied women ranged from 9 to18 years with a mean of $13.46 \pm 1.94$ years. One quarter of the women reported that they have irregular menses, less than two fifths $(37.7 \%)$ suffered from absence of menses since three months. Slightly more than two fifths $(40.8 \%)$ of the women reached menopause with a mean age $47.14 \pm 4.23$ years. $66.03 \%$ of the studied women reached menopause at the age ranged from 40 to 50 years.

Table (4) shows that slightly more than one tenth $(11.5 \%)$ of the women has previous history of exposure to fracture, $40 \%$ of them exposed once or twice to fracture and $20 \%$ of them reported that they have three times fracture with a mean of $1.8 \pm 0.76$ times. Fifty percent of those were exposed to fracture have fracture of the arm, followed by $40 \%$ at leg and $30 \%$ at thigh and wrist and $10 \%$ at shoulder.

Table (5) portrays that the total mean subscale of susceptibility to osteoporosis was $15.91 \pm 5.67$ which reflect low perceived susceptibility to osteoporosis; moreover the total mean subscale of seriousness was $18.31 \pm 4.30$ that also reflect low perceived seriousness to osteoporosis.

Table (6) presents that the total mean subscale of benefit of exercise was $22.68 \pm 4.30$ which indicates high perceived benefit of exercise in preventing 
osteoporosis, additionally total mean subscale for benefit of calcium was 23.86 \pm 3.23 , which indicates high perceived benefit of calcium in preventing osteoporosis.

Table(7) shows that it is positively to found that the total means subscale of barrier of exercise was $18.41 \pm 3.87$ which indicates low perceived barrier of exercise in preventing osteoporosis and $17.47 \pm 4.22$ for barrier to calcium which indicates low perceived barrier of calcium in preventing osteoporosis. Also, this table presents that the total means subscale of health motivation was $21.00 \pm 3.40$ which indicates positive view toward osteoporosis prevention.

Table (8) shows that around two thirds $(63.5 \%)$ of the women have low perceived susceptibility to osteoporosis, more than half $(57.3 \%)$ of the women have low perceived seriousness to osteoporosis, while more than three quarters $(77.7 \%)$ of the women have high perceived benefit of exercise, and the majority $(90.4 \%)$ of the women have high perceived benefit of calcium in decreasing the risk to osteoporosis. Slightly more than half $(51.9 \%)$ of the women have low perceived barrier to exercise, and slightly less than two thirds $(62.7 \%)$ of the women have low perceived barrier to calcium in decreasing the risk to osteoporosis. Finally, more than two thirds $(68.1 \%)$ of the women have positive view of health motivation.

Table (9) explores a significant relation between levels of education of the women and all subscales of health belief model, a significant relation was observed between marital status of the women and susceptibility, benefit of exercise, benefit of calcium, barriers to exercise, barriers to calcium and health motivation subscales of health belief model. Moreover, a significant relation was noted between age and occupation of the women and all subscales of health belief model except health motivation subscale, regarding income there is no significant relation between income and susceptibility, seriousness and health motivation subscales of health belief model.
Table (10) portrays a significant relation between women who have health problems and seriousness subscale of health belief model. Moreover, the table shows that there is a significant relation between BMI and all health belief model subscales except benefit and barrier of calcium and health motivation subscale.

Table (11) shows a significant relation between age at menarche of the women and all subscales of health belief model. Moreover, a significant relation was observed between irregularity of menses among the women and susceptibility, benefit of exercise and calcium, and barriers to calcium subscales of health belief model, regarding absence of menses for three months, there is a significant relation observed between all subscales of health belief model except seriousness subscale. Additionally, there is a significant relation between susceptibility, benefit of exercise and calcium, and barriers to exercises and health motivation subscales of health belief model and menopausal women. Finally, a significant relation was observed between women's age at menopause and all subscales of health belief model.

Table (12) a significant relation was observed between positive family history of osteoporosis among the women and susceptibility, seriousness, benefit of exercise and barriers to calcium subscales of health belief model. Regarding previous exposure to fracture among the women, there is a significant relation was observed between it and seriousness and benefit of exercise subscales of health belief model. Finally, there is a significant relation between the number of time of the women exposure to fracture and susceptibility, benefit of exercises and calcium, barriers to exercise and exercise and health motivation subscales of health belief model.

\section{Discussion}

Osteoporosis is a preventable chronic disease that begins during childhood. It is a silent killer not diagnosed until an individual presents with a low impact 
fracture. Health belief model (HBM) based intervention increases awareness about risk factors and preventive behaviors ${ }^{(15)}$. The Health Belief Model is a widely-used conceptual framework to explain and predict health-related behaviors. Previous studies suggest that health beliefs are important determinants of whether individuals participate in health screening or $\operatorname{not}^{(16)}$.

The HBM proposes that if individuals who adopt osteoporosis preventive measures, must feel susceptible to osteoporosis, believe that occurrence of osteoporosis would have a severe impact on their lives, and conclude that preventive measures are beneficial, outweighing any barriers involved in taking the actions ${ }^{(17)}$. The current study revealed that, the mean score of studied women who believed that there is a good chance that will get osteoporosis was low (table 5). This reflects that the studied women didn't feel and consider themselves susceptible to osteoporosis which may put them at risk for osteoporosis. Additionally the result of current study showed that around two thirds of the women have low perceived susceptibility to osteoporosis (table 8), this is consistent with findings of the study done by Edmonds E. et al. (2012) who found that the participant of his study did not feel susceptible to osteoporosis and added that according to the HBM, the participants will not take preventative measures to the disease, the same findings were confirmed by Al Seraty (2014) and Nayak S. et al. $(2010)^{(15-17)}$.

Concerning the seriousness of osteoporosis the studied women had low perception as indicated by the mean regarding the beliefs that if they had osteoporosis they would be crippled. This finding may be due to lack of the studied women knowledge about osteoporosis, high risk group, severity and complication of a disease.

In fact, total mean subscale of each health belief model construct must be interpreted to indicate low or high perception in the possibility of prevention of osteoporosis that support the role of community health nurse in applying preventive program. In this regard the current study portrayed that, the total mean subscale of susceptibility to osteoporosis reflect low perceived susceptibility to osteoporosis, moreover the total mean subscale of seriousness also reflect low perceived seriousness to osteoporosis (table 8). These findings were support the findings of the survey done in India, 2014 by Jeihooni A. et al. ${ }^{(18)}$ and in Saudi Arabia 2014 by Al Seraty ${ }^{(15)}$. Additionally, McLeod KM (2011) found a greater perceived seriousness, benefits, selfefficacy, health motivation, and fewer barriers were the most common healthbelief subscales in men and women in his study $^{(19)}$.

Women are more likely to engage in osteoporosis prevention behavior to prevent or slow bone density loss if they perceive themselves to be more susceptible to osteoporosis, believe that osteoporosis is a serious threat, believe that they can modify their risks, perceive fewer negative aspects to be associated with preventive behaviors, have a concern and drive for their general health, and believe that they can perform these behaviors (Sedlak C et al, 2007) ${ }^{(20)}$. To understand ways to motivate women to initiate and continue health promotion activities designed to maintain or increase bone density; health beliefs must be assessed to determine how to influence more women to begin and adhere to lifestyle changes/actions designed to prevent osteoporosis. The results of assessment provide support for earlier interventions to promote primary and secondary prevention of osteoporosis ${ }^{(20)}$.

For many people, exercise is a part of their life and a diagnosis of osteoporosis or fragile bones should not mean this has to stop. Specifically women need regular exercise to decrease bone loss particularly after menopause ${ }^{(21)}$. In this regard the finding of the present study revealed that the beliefs of the studied women in the benefits of exercise were high as they belief that regular exercise help to build strong 
bones and exercising to prevent osteoporosis also improves the way their body look (table 6). This finding could be related to that all women are adults and the majority of them were educated to have recognition to the importance of exercise not only in the prevention of osteoporosis but also in the promotion of their health.

Calcium is the healthy bone mineral. About $99 \%$ of calcium in the body is stored in the bone. Adults need calcium to maintain a strong bone and protect them from osteoporosis and fracture. Over time inadequate calcium intake can cause osteoporosis $^{(22)}$. In the present study, there was a high perception of calcium intake in the prevention of osteoporosis as indicated by a mean score regarding taking enough calcium prevents painful osteoporosis and cuts down the chance of broken bones (table 6).

Moreover, health motivation has been found to be related to degree of readiness of people to engage in health behavior ${ }^{(23)}$. In the current study, the studied women had a positive view regarding health motivation measures related to health such as eat a well balanced diet, having regular checkup and follow up recommendations to keep healthy (table 6).

Also, the current study reported that the total mean subscale of benefit of exercise indicates high perceived benefit of exercise in preventing osteoporosis, additionally total mean subscale for benefit of calcium indicates high perceived benefit of calcium in preventing osteoporosis. Finally, the total means subscale of health motivation indicates positive view toward osteoporosis prevention (table 8). These findings were consistent with Jeihooni A. et al. (2014) and Edmonds E (2012) $)^{(17,18)}$. Moreover, Deo P. et al. (2013) added that, the perceptions of benefits of osteoporosis screening and the perceived barriers were found to be of greater importance in women's decisions to engage in osteoporosis-specific preventive behavior that was confirmed by the findings of the current study ${ }^{(10)}$.
The current study explores a significant relation between levels of education of the women and all subscales of health belief model, a significant relation was observed between marital status of the women and susceptibility, benefit of exercise, benefit of calcium, barriers to exercise, barriers to calcium and health motivation subscales of health belief model. Moreover, a significant relation was noted between age and occupation of the women and all subscales of health belief model except health motivation subscale, regarding income there is no significant relation between income and susceptibility, seriousness and health motivation subscales of health belief model (table 9). In contrast, Deo P. (2013) declared that perceptions of severity and susceptibility towards osteoporosis and subjects' demographic characteristics did not seem to significantly influence the decision to screen ${ }^{(10)}$.

The current study shows that there is a significant relation between body mass index and all health belief model subscales except benefit and barrier of calcium and health motivation subscale (table 10), which in line with Nayak S. et al. (2010) findings; as they found that weight is significantly associated with belief in osteoporosis susceptibility ${ }^{(16)}$. Moreover, a significant relation was observed in the current study between positive family history of osteoporosis among the women and susceptibility, seriousness, benefit of exercise and barriers to calcium subscales of health belief model. Regarding previous exposure to fracture among the women, there is a significant relation was observed between it and seriousness and benefit of exercise subscales of health belief model. Finally, there is a significant relation between the number of time of the women exposure to fracture and susceptibility, benefit of exercises and calcium, barriers to exercise and exercise and health motivation subscales of health belief model (table 12).

In this regard, Nayak S. (2010) found that family history of osteoporosis, and prior testing for osteoporosis was significantly associated with belief in osteoporosis 
severity. Moreover, personal and family history of osteoporosis was significantly associated with belief in osteoporosis susceptibility $^{(16)}$. In contrast, Al-Otaibi, H.H. (2015) added that, based on the Osteoporosis Health Belief Scale (OHBS) subscale mean score, the perceived susceptibility and perceived severity were lower in women without family history with a significant difference between the groups. The family history group had lower mean score barriers of calcium intake and exercise with a significant difference between groups $^{(24)}$.

\section{Conclusion}

From the study results it can be concluded that the studied women had low perceptions of susceptibility and severity of osteoporosis, this is an area of concern since the perceptions of susceptibility and severity of the disease are two key factors that shape and impact the future preventive behavior. Despite, they had higher perception of benefits of exercise and calcium in preventing osteoporosis. Moreover, they had positive heath view regarding health motivation related to health.

\section{Recommendations}

In the light of the present findings, the following recommendations could be made:

1- Raise public awareness about osteoporosis including the extent of the problem and means for overcoming it. This could be done through media, awareness campaigns and community mobilization.

2- Enhance the role of IEC (Information, Education, and Communication) in meeting the women's knowledge gap in relation to preventive measures of osteoporosis.

3- Strength osteoporosis prevention strategy and services such as developing extensive screening program for all women above 40 years.

4- Follow up and accurate recording for cases is highly important.

5- Special attention should be given to high risk groups.

6- The use of an osteoporosis educational problem seems to improve knowledge and health beliefs.

7- Strengthen outreach programs to promote preventive measures toward osteoporosis among all women.

Recommendation for future studies:

- Encourage future larger community based studies on osteoporosis considering gender differences. 
Table (1): Distribution of the studied women according to their socio-demographic characteristics

\begin{tabular}{|c|c|c|}
\hline \multirow[t]{2}{*}{ Socio-demographic characteristics } & \multicolumn{2}{|c|}{$\begin{array}{c}\text { Frequency } \\
\text { n(260) }\end{array}$} \\
\hline & No & $\%$ \\
\hline \multicolumn{3}{|l|}{ Age (Years) } \\
\hline 40 to less than 45 & 83 & 31.9 \\
\hline 45 to less than 50 & 70 & 26.9 \\
\hline 50 to less than 55 & 39 & 15.0 \\
\hline 55 to less than 60 & 43 & 16.5 \\
\hline 60 and more & 25 & 9.6 \\
\hline Mean \pm SD & \multicolumn{2}{|c|}{$49.27 \pm 8.573$} \\
\hline \multicolumn{3}{|l|}{\begin{tabular}{|l} 
Marital status \\
\end{tabular}} \\
\hline Single & 36 & 13.8 \\
\hline Married & 170 & 65.4 \\
\hline Widow & 39 & 15.0 \\
\hline Divorced & 15 & 5.8 \\
\hline \multicolumn{3}{|l|}{ Have children } \\
\hline $1-2$ & 75 & 28.8 \\
\hline $3-4$ & 91 & 35 \\
\hline 5 and more & 26 & 10 \\
\hline Mean \pm SD & \multicolumn{2}{|c|}{$3.01 \pm 1.249$} \\
\hline \multicolumn{3}{|l|}{ Place of residence } \\
\hline Urban & 247 & 95.0 \\
\hline Rural & 13 & 5.0 \\
\hline \multicolumn{3}{|l|}{ Level of education } \\
\hline Illiterate & 24 & 9.2 \\
\hline Read and write & 6 & 2.3 \\
\hline Preparatory & 9 & 3.5 \\
\hline Average(secondary) & 115 & 44.2 \\
\hline Above average & 32 & 12.3 \\
\hline High education & 62 & 23.8 \\
\hline Post graduate & 12 & 4.6 \\
\hline \multicolumn{3}{|l|}{ Occupation } \\
\hline Not working & 140 & 53.8 \\
\hline Working & 120 & 46.2 \\
\hline \multicolumn{3}{|l|}{\begin{tabular}{|l|} 
Income \\
\end{tabular}} \\
\hline Enough and save & 63 & 24.2 \\
\hline Enough and didn't save & 147 & 56.5 \\
\hline Didn't save & 50 & 19.2 \\
\hline
\end{tabular}


Table (2): Distribution of the studied women according to their past medical history

\begin{tabular}{|c|c|c|}
\hline \multirow[t]{2}{*}{ Past medical history } & \multicolumn{2}{|c|}{$\begin{array}{c}\text { Frequency } \\
\text { n(260) }\end{array}$} \\
\hline & No & $\%$ \\
\hline \multicolumn{3}{|l|}{ Previous history of health problems } \\
\hline Yes & 207 & 79.6 \\
\hline No & 53 & 20.4 \\
\hline Types of health problems* & $\mathbf{n}(\mathbf{2 0 7})$ & \\
\hline Hypertension & 95 & 45.9 \\
\hline Arthritis & 88 & 42.5 \\
\hline High cholesterol level & 85 & 41.1 \\
\hline $\mathrm{DM}$ & 61 & 29.5 \\
\hline Liver disease & 30 & 14.5 \\
\hline Goiter & 18 & 8.7 \\
\hline Renal disease & 15 & 7.2 \\
\hline Gout & 6 & 2.9 \\
\hline Lumber disc & 3 & 1.4 \\
\hline Osteoporosis & 3 & 1.4 \\
\hline Received medication & $\mathbf{n}(\mathbf{2 6 0})$ & \\
\hline Yes & 100 & 38.5 \\
\hline No & 160 & 61.5 \\
\hline Types of medication received* & $\mathbf{n}(\mathbf{1 0 0})$ & \\
\hline Diuretics & 61 & 61 \\
\hline Corticosteroid & 24 & 24 \\
\hline Hormonal replacement & 20 & 20 \\
\hline Thyroxin replacement & 12 & 12 \\
\hline Analgesic & 12 & 12 \\
\hline Gout therapy & 6 & 6 \\
\hline Heparin & 3 & 3 \\
\hline Previous surgery & $\mathbf{n}(\mathbf{2 6 0})$ & \\
\hline Yes & 36 & 13.8 \\
\hline No & 224 & 86.1 \\
\hline Types of surgery & $\mathbf{n}(36)$ & \\
\hline Mastectomy & 3 & 8.3 \\
\hline Oophorectomy & 14 & 38.9 \\
\hline Hysterectomy & 19 & 52.8 \\
\hline \multicolumn{3}{|l|}{ BMI } \\
\hline Underweight $\left(\right.$ Less than $\left.18 \mathrm{~kg} / \mathrm{m}^{2}\right)$ & 3 & 1.2 \\
\hline Normal weight (18 to $24.9 \mathrm{~kg} / \mathrm{m}^{2}$ ) & 56 & 21.5 \\
\hline Overweight $\quad\left(25-29.9 \mathrm{~kg} / \mathrm{m}^{2}\right)$ & 75 & 28.8 \\
\hline Obese class I $\quad\left(30-34.9 \mathrm{~kg} / \mathrm{m}^{2}\right)$ & 82 & 31.5 \\
\hline Obese class II $\quad\left(35-39.9 \mathrm{~kg} / \mathrm{m}^{2}\right)$ & 33 & 12.7 \\
\hline Obese class III $\left(40 \mathrm{~kg}\right.$ and more $\left./ \mathrm{m}^{2}\right)$ & 11 & 4.2 \\
\hline
\end{tabular}

* More than answer 
Table (3): Distribution of the studied women according to their menstrual history

\begin{tabular}{||l|c|c||}
\hline \multirow{2}{*}{ Menstrual history } & \multicolumn{2}{|c|}{ Frequency } \\
n(260)
\end{tabular}


Table (4): Distribution of the studied women according to their history of previous fracture

\begin{tabular}{||l|c|c||}
\hline \multirow{2}{*}{ History of fracture } & \multicolumn{2}{|c||}{ Frequency } \\
\cline { 2 - 3 } Previous history of exposure to fracture & No & $\%$ \\
\hline Yes & 30 & 11.5 \\
\hline No & 230 & 88.5 \\
\hline Number of time of previous exposure to fracture & $\mathbf{n}(\mathbf{3 0})$ & \\
\hline Once & 12 & 40 \\
\hline Two & 12 & 40 \\
\hline Three & 6 & 20 \\
\hline Mean \pm SD & \multicolumn{1}{|c||}{$1.8 \pm 0.76$} \\
\hline Site of fracture* & $\mathbf{n}(\mathbf{3 0})$ & \\
\hline Arm & 15 & 50 \\
\hline Leg & 12 & 40 \\
\hline Thigh & 9 & 30 \\
\hline Wrist & 9 & 30 \\
\hline Shoulder & 3 & 10 \\
\hline
\end{tabular}

* More than answer 
Table (5): Distribution of the studied women health beliefs regarding susceptibility and seriousness of osteoporosis using the Health Belief Model

\begin{tabular}{|c|c|c|c|}
\hline \multirow[b]{2}{*}{ Statements } & \multicolumn{2}{|c|}{ Responses } & \multirow{2}{*}{$\begin{array}{c}\text { Interpretation for the } \\
\text { total mean for each } \\
\text { subscale }\end{array}$} \\
\hline & Mean & $\begin{array}{l}\text { Standard } \\
\text { deviation }\end{array}$ & \\
\hline \multicolumn{4}{|l|}{ Susceptibility to osteoporosis } \\
\hline $\begin{array}{l}\text { 1. Your chances of getting } \\
\text { osteoporosis are high. }\end{array}$ & 2.72 & 1.110 & \multirow{7}{*}{$\begin{array}{c}\text { Low perceived } \\
\text { susceptibility to } \\
\text { osteoporosis (mean } \\
\text { ranged from 6-18.9) }\end{array}$} \\
\hline $\begin{array}{l}\text { 2. Because of your body build, you } \\
\text { are more likely to develop } \\
\text { osteoporosis. }\end{array}$ & 2.70 & 1.074 & \\
\hline $\begin{array}{l}\text { 3. It is extremely likely that you will } \\
\text { get osteoporosis. }\end{array}$ & 2.78 & 1.196 & \\
\hline $\begin{array}{l}\text { 4. There is a good chance that you } \\
\text { will get osteoporosis. }\end{array}$ & 2.67 & 1.097 & \\
\hline $\begin{array}{l}\text { 5. You are more likely than the } \\
\text { average person to get osteoporosis. }\end{array}$ & 2.72 & 1.108 & \\
\hline $\begin{array}{l}\text { 6. Your family history makes it more } \\
\text { likely that you will get } \\
\text { osteoporosis. }\end{array}$ & 2.33 & .903 & \\
\hline $\begin{array}{l}\text { Total mean subscale (A possible range of } \\
6 \text { to } 30 \text { ) }\end{array}$ & 15.91 & 5.67 & \\
\hline \multicolumn{4}{|l|}{ Seriousness to osteoporosis } \\
\hline $\begin{array}{l}\text { 7. The thought of having osteoporosis } \\
\text { scares you. }\end{array}$ & 3.15 & 1.100 & \multirow{7}{*}{$\begin{array}{c}\text { Low perceived } \\
\text { seriousness to } \\
\text { osteoporosis (mean } \\
\text { ranged from 6-18.9) }\end{array}$} \\
\hline $\begin{array}{l}\text { 8. If you had osteoporosis you would } \\
\text { be crippled. }\end{array}$ & 2.10 & .988 & \\
\hline $\begin{array}{l}\text { 9. Your feelings about yourself would } \\
\text { change if you got osteoporosis. }\end{array}$ & 3.22 & 3.423 & \\
\hline $\begin{array}{l}\text { 10. It would be very costly if you got } \\
\text { osteoporosis. }\end{array}$ & 3.36 & 1.032 & \\
\hline $\begin{array}{l}\text { 11. When you think about osteoporosis } \\
\text { you get depressed. }\end{array}$ & 3.21 & 1.075 & \\
\hline $\begin{array}{l}\text { 12. It would be very serious if you get } \\
\text { osteoporosis. }\end{array}$ & 4.21 & 5.577 & \\
\hline $\begin{array}{l}\text { Total mean subscale (A possible range of } \\
6 \text { to } 30 \text { ) }\end{array}$ & 18.31 & 4.30 & \\
\hline
\end{tabular}


Table (6): Distribution of the studied women health beliefs regarding benefits of exercises and calcium intake using the Health Belief Model

\begin{tabular}{|c|c|c|c|}
\hline \multirow[b]{2}{*}{ Statements } & \multicolumn{2}{|c|}{ Responses } & \multirow{2}{*}{$\begin{array}{c}\text { Interpretation for the } \\
\text { total mean for each } \\
\text { subscale }\end{array}$} \\
\hline & Mean & $\begin{array}{l}\text { Standard } \\
\text { deviation }\end{array}$ & \\
\hline \multicolumn{4}{|l|}{ Benefits of exercises } \\
\hline $\begin{array}{l}\text { 1. Regular exercise prevents } \\
\text { problems that happen from } \\
\text { osteoporosis. }\end{array}$ & 3.80 & .868 & \multirow{7}{*}{$\begin{array}{c}\text { High perceived } \\
\text { benefit of exercise in } \\
\text { preventing } \\
\text { osteoporosis (mean } \\
\text { ranged from 19-30) }\end{array}$} \\
\hline $\begin{array}{l}\text { 2. You feel better when you exercise } \\
\text { to prevent osteoporosis. }\end{array}$ & 3.74 & .843 & \\
\hline $\begin{array}{l}\text { 3. Regular exercise helps to build } \\
\text { strong bones. }\end{array}$ & 3.84 & .821 & \\
\hline $\begin{array}{l}\text { 4. Exercising to prevent osteoporosis } \\
\text { also improves the way your body } \\
\text { looks. }\end{array}$ & 3.82 & .742 & \\
\hline $\begin{array}{l}\text { 5. Regular exercise cuts down the } \\
\text { chances of broken bones. }\end{array}$ & 3.76 & 850 & \\
\hline $\begin{array}{l}\text { 6. You feel good about yourself when } \\
\text { you exercise to prevent } \\
\text { osteoporosis. }\end{array}$ & 3.72 & .862 & \\
\hline $\begin{array}{l}\text { Total mean subscale (A possible range of } \\
6 \text { to } 30 \text { ) }\end{array}$ & 22.68 & 4.30 & \\
\hline \multicolumn{4}{|l|}{ Benefits of calcium } \\
\hline $\begin{array}{l}\text { 7. Taking in enough calcium prevents } \\
\text { problems from osteoporosis. }\end{array}$ & 3.92 & .741 & \multirow{7}{*}{$\begin{array}{c}\text { High perceived } \\
\text { benefit of calcium in } \\
\text { preventing } \\
\text { osteoporosis (mean } \\
\text { ranged from 19-30) }\end{array}$} \\
\hline $\begin{array}{l}\text { 8. You have lots to gain from taking } \\
\text { in enough calcium to prevent } \\
\text { osteoporosis. }\end{array}$ & 3.94 & .692 & \\
\hline $\begin{array}{l}\text { 9. Taking in enough calcium prevents } \\
\text { painful osteoporosis. }\end{array}$ & 4.07 & .671 & \\
\hline $\begin{array}{l}\text { 10. You would not worry as much } \\
\text { about osteoporosis if you took in } \\
\text { enough calcium. }\end{array}$ & 3.98 & .651 & \\
\hline $\begin{array}{l}\text { 11. Taking in enough calcium cuts } \\
\text { down on your chances of broken } \\
\text { bones. }\end{array}$ & 4.03 & .621 & \\
\hline $\begin{array}{l}\text { 12. You feel good about yourself when } \\
\text { you take in enough calcium to } \\
\text { prevent osteoporosis. }\end{array}$ & 3.93 & .608 & \\
\hline $\begin{array}{l}\text { Total mean subscale (A possible range of } \\
6 \text { to } 30 \text { ) }\end{array}$ & 23.86 & 3.23 & \\
\hline
\end{tabular}


Table (7): Distribution of the studied women health beliefs regarding barriers to exercises, calcium intake and health motivation

\begin{tabular}{|c|c|c|c|}
\hline \multirow[b]{2}{*}{ Statements } & \multicolumn{2}{|c|}{ Responses } & \multirow{2}{*}{$\begin{array}{c}\text { Interpretation for } \\
\text { the total mean for } \\
\text { each subscale }\end{array}$} \\
\hline & Mean & $\begin{array}{l}\text { Standard } \\
\text { deviation }\end{array}$ & \\
\hline \multicolumn{4}{|l|}{ Barriers to exercises } \\
\hline $\begin{array}{l}\text { 1. You feel like you are not strong enough to } \\
\text { exercise regularly. }\end{array}$ & 3.40 & .897 & \multirow{7}{*}{$\begin{array}{l}\text { low perceived } \\
\text { barrier of } \\
\text { exercise in } \\
\text { preventing } \\
\text { osteoporosis } \\
\text { (mean ranged } \\
\text { from 6-18.9) }\end{array}$} \\
\hline $\begin{array}{l}\text { 2. You have no place where you can } \\
\text { exercise. }\end{array}$ & 3.06 & 1.012 & \\
\hline $\begin{array}{l}\text { 3. Your spouse or family discourages you } \\
\text { from exercising. }\end{array}$ & 2.96 & 1.022 & \\
\hline $\begin{array}{l}\text { 4. Exercising regularly would mean starting } \\
\text { a new habit which is hard for you to do. }\end{array}$ & 3.20 & .904 & \\
\hline $\begin{array}{l}\text { 5. Exercising regularly makes you } \\
\text { uncomfortable. }\end{array}$ & 2.81 & 1.028 & \\
\hline $\begin{array}{l}\text { 6. Exercising regularly upsets your every } \\
\text { day routine. }\end{array}$ & 2.99 & .963 & \\
\hline $\begin{array}{l}\text { Total mean subscale (A possible range of } 6 \text { to } \\
30 \text { ) }\end{array}$ & 18.41 & 3.87 & \\
\hline \multicolumn{4}{|l|}{ Barriers to calcium } \\
\hline 7. Calcium rich foods cost too much. & 3.08 & .893 & \multirow{7}{*}{$\begin{array}{l}\text { Low perceived } \\
\text { barrier of calcium } \\
\text { in preventing } \\
\text { osteoporosis } \\
\text { (mean ranged } \\
\text { from 6-18.9) }\end{array}$} \\
\hline 8. Calcium rich foods do not agree with you. & 2.58 & 1.009 & \\
\hline 9. You do not like calcium rich food. & 2.68 & 1.055 & \\
\hline $\begin{array}{l}\text { 10. Eating calcium rich foods means changing } \\
\text { your diet which is hard to do. }\end{array}$ & 3.00 & .940 & \\
\hline $\begin{array}{l}\text { 11. In order to eat more calcium rich foods } \\
\text { you have give up other foods that you } \\
\text { like. }\end{array}$ & 2.93 & .962 & \\
\hline $\begin{array}{l}\text { 12. Calcium rich foods have too much } \\
\text { cholesterol. }\end{array}$ & 3.21 & .923 & \\
\hline $\begin{array}{l}\text { Total mean subscale (A possible range of } 6 \text { to } \\
30 \text { ) }\end{array}$ & 17.47 & 4.22 & \\
\hline \multicolumn{4}{|l|}{ Health motivation } \\
\hline 13. You eat a well-balanced diet. & 3.67 & 3.314 & \multirow{7}{*}{$\begin{array}{l}\text { Positive health } \\
\text { view (mean } \\
\text { ranged from 19- } \\
\text { 30) }\end{array}$} \\
\hline $\begin{array}{l}\text { 14. You look for new information related to } \\
\text { health. }\end{array}$ & 3.63 & .782 & \\
\hline 15. Keeping healthy is very important for you. & 3.87 & .650 & \\
\hline 16. You try to discover health problems early. & 3.62 & .869 & \\
\hline $\begin{array}{l}\text { 17. You have a regular health check-up even } \\
\text { when you are not sick. }\end{array}$ & 3.02 & 1.069 & \\
\hline $\begin{array}{l}\text { 18. You follow recommendations to keep you } \\
\text { healthy. }\end{array}$ & 3.53 & .821 & \\
\hline $\begin{array}{l}\text { Total mean subscale (A possible range of } 6 \text { to } \\
30 \text { ) }\end{array}$ & 21.00 & 3.40 & \\
\hline
\end{tabular}


Table (8): Distribution of the studied women according to the mean subscale of Osteoporosis Health Belief Model

\begin{tabular}{|c|c|c|}
\hline HBM of osteoporosis subscale category & No & $\%$ \\
\hline \multicolumn{3}{|l|}{ Perceived Susceptibility to osteoporosis } \\
\hline - $\quad$ Low perceived (mean ranged from 6-18.9) & 165 & 63.5 \\
\hline - $\quad$ High perceived (mean ranged from 19-30) & 95 & 36.5 \\
\hline \multicolumn{3}{|l|}{ Perceived Seriousness to osteoporosis } \\
\hline - $\quad$ Low perceived (mean ranged from 6-18.9) & 149 & 57.3 \\
\hline - $\quad$ High perceived (mean ranged from 19-30) & 111 & 42.7 \\
\hline \multicolumn{3}{|l|}{ Perceived Benefits of exercises } \\
\hline - $\quad$ Low perceived (mean ranged from 6-18.9) & 58 & 22.3 \\
\hline - $\quad$ High perceived (mean ranged from 19-30) & 202 & 77.7 \\
\hline \multicolumn{3}{|l|}{ Perceived Benefits of calcium } \\
\hline - $\quad$ Low perceived (mean ranged from 6-18.9) & 25 & 9.6 \\
\hline - $\quad$ High perceived (mean ranged from 19-30) & 235 & 90.4 \\
\hline \multicolumn{3}{|l|}{ Perceived Barriers to exercises* } \\
\hline - $\quad$ Low perceived (mean ranged from 6-18.9) & 135 & 51.9 \\
\hline - $\quad$ High perceived (mean ranged from 19-30) & 125 & 48.1 \\
\hline \multicolumn{3}{|l|}{ Perceived Barriers to calcium* } \\
\hline - $\quad$ Low perceived (mean ranged from 6-18.9) & 163 & 62.7 \\
\hline - $\quad$ High perceived (mean ranged from 19-30) & 97 & 37.3 \\
\hline \multicolumn{3}{|l|}{ Health motivation } \\
\hline - $\quad$ Negative view (mean ranged from 6-18.9) & 83 & 31.9 \\
\hline - $\quad$ Positive view (mean ranged from 19-30) & 177 & 68.1 \\
\hline
\end{tabular}

* Higher scores indicates negative health belief toward osteoporosis prevention 
Women's Health Beliefs Regarding Osteoporosis

Table (9): Relation between socio-demographic characteristics of the studied women and components of 0steoporosis Health Belief Model

\begin{tabular}{|c|c|c|c|c|c|c|c|c|c|c|c|c|c|c|}
\hline \multirow{3}{*}{$\begin{array}{l}\text { Socio- } \\
\text { demographic } \\
\text { characteristic }\end{array}$} & \multicolumn{14}{|c|}{ Osteoporosis Health Belief Model } \\
\hline & \multicolumn{2}{|c|}{$\begin{array}{l}\text { Susceptibility } \\
\text { to osteoporosis }\end{array}$} & \multicolumn{2}{|c|}{$\begin{array}{c}\text { Seriousness to } \\
\text { osteoporosis }\end{array}$} & \multicolumn{2}{|c|}{$\begin{array}{l}\text { Benefits of } \\
\text { exercises }\end{array}$} & \multicolumn{2}{|c|}{$\begin{array}{l}\text { Benefits of } \\
\text { calcium }\end{array}$} & \multicolumn{2}{|c|}{$\begin{array}{c}\text { Barriers to } \\
\text { exercises }\end{array}$} & \multicolumn{2}{|c|}{$\begin{array}{l}\text { Barriers to } \\
\text { calcium }\end{array}$} & \multicolumn{2}{|c|}{$\begin{array}{c}\text { Health } \\
\text { motivation }\end{array}$} \\
\hline & $\mathrm{F}$ & $\mathrm{P}$ & $\mathrm{F}$ & $P$ & $\mathrm{~F}$ & $\mathrm{P}$ & $\mathrm{F}$ & $\mathrm{P}$ & $\mathrm{F}$ & $\mathrm{P}$ & $\mathrm{F}$ & $\mathrm{P}$ & $\mathrm{F}$ & $\mathrm{P}$ \\
\hline $\begin{array}{l}\text { Level of } \\
\text { education }\end{array}$ & 5.304 & $* 0.000$ & 11.396 & $* 0.000$ & 3.114 & $* 0.006$ & 8.195 & ${ }^{*} 0.000$ & 3.698 & $* 0.002$ & 7.242 & $* 0.000$ & 2.823 & $* 0.011$ \\
\hline Marital status & 13.946 & $* 0.000$ & 1.513 & 0.212 & 5.656 & $* 0.001$ & 8.326 & $* 0.000$ & 2.785 & $* 0.041$ & 3.654 & $* 0.013$ & 2.531 & $* 0.058$ \\
\hline Age & 9.329 & $* 0.000$ & 5.050 & ${ }^{*} 0.001$ & 22.119 & $* 0.000$ & 8.008 & ${ }^{*} 0.000$ & 25.850 & ${ }^{*} 0.000$ & 7.491 & $* 0.000$ & 1.267 & 0.283 \\
\hline Occupation & 9.686 & $* 0.000$ & 6.004 & ${ }^{*} 0.001$ & 10.158 & $* 0.000$ & 8.001 & ${ }^{*} 0.000$ & 18.821 & ${ }^{*} 0.000$ & 12.274 & $* 0.000$ & 2.063 & 0.106 \\
\hline Income & .346 & 0.708 & .910 & 0.404 & 3.336 & $* 0.037$ & 12.460 & ${ }^{*} 0.000$ & 3.901 & $* 0.021$ & 3.580 & $* 0.029$ & 0.947 & 0.389 \\
\hline
\end{tabular}

F: ANOVA Test

* Significance at $\mathrm{P} \leq 0.05$ 
Women's Health Beliefs Regarding Osteoporosis

Table (10): Relation between health history of the studied women and 0steoporosis Health Belief Model

\begin{tabular}{|c|c|c|c|c|c|c|c|c|c|c|c|c|c|c|}
\hline \multirow{3}{*}{$\begin{array}{l}\text { Health } \\
\text { history }\end{array}$} & \multicolumn{14}{|c|}{ Osteoporosis Health Belief Model } \\
\hline & \multicolumn{2}{|c|}{$\begin{array}{l}\text { Susceptibility } \\
\text { to osteoporosis }\end{array}$} & \multicolumn{2}{|c|}{$\begin{array}{c}\text { Seriousness to } \\
\text { osteoporosis }\end{array}$} & \multicolumn{2}{|c|}{$\begin{array}{l}\text { Benefits of } \\
\text { exercises }\end{array}$} & \multicolumn{2}{|c|}{$\begin{array}{l}\text { Benefits of } \\
\text { calcium }\end{array}$} & \multicolumn{2}{|c|}{$\begin{array}{c}\text { Barriers to } \\
\text { exercises }\end{array}$} & \multicolumn{2}{|c|}{$\begin{array}{c}\text { Barriers to } \\
\text { calcium }\end{array}$} & \multicolumn{2}{|c|}{$\begin{array}{c}\text { Health } \\
\text { motivation }\end{array}$} \\
\hline & $\mathrm{F}$ & $P$ & $\mathrm{~F}$ & $P$ & $\mathrm{~F}$ & $P$ & $\mathrm{~F}$ & $P$ & $\mathrm{~F}$ & $P$ & $\mathrm{~F}$ & $P$ & $\mathrm{~F}$ & $P$ \\
\hline $\begin{array}{l}\text { Have health } \\
\text { problems }\end{array}$ & 2.430 & 0.120 & 21.573 & $* 0.000$ & .315 & 0.575 & 1.233 & 0.268 & 1.643 & 0.201 & .493 & 0.483 & 2.430 & 0.120 \\
\hline BMI & 4.600 & $* 0.000$ & 3.586 & $* 0.004$ & 2.176 & $* 0.057$ & 1.134 & 0.343 & 2.808 & $* 0.017$ & 2.694 & 0.22 & 4.600 & $* 0.000$ \\
\hline
\end{tabular}

F: ANOVA Test

* Significance at $\mathrm{P} \leq 0.05$ 
Women's Health Beliefs Regarding Osteoporosis

Table (11): Relation between menstrual history of the studied women and Osteoporosis Health Belief Model

\begin{tabular}{|c|c|c|c|c|c|c|c|c|c|c|c|c|c|c|}
\hline \multirow{3}{*}{$\begin{array}{l}\text { Menstrual } \\
\text { history }\end{array}$} & \multicolumn{14}{|c|}{ Osteoporosis Health Belief Model } \\
\hline & \multicolumn{2}{|c|}{$\begin{array}{c}\text { Susceptibility to } \\
\text { osteoporosis }\end{array}$} & \multicolumn{2}{|c|}{$\begin{array}{c}\text { Seriousness to } \\
\text { osteoporosis }\end{array}$} & \multicolumn{2}{|c|}{$\begin{array}{l}\text { Benefits of } \\
\text { exercises }\end{array}$} & \multicolumn{2}{|c|}{$\begin{array}{l}\text { Benefits of } \\
\text { calcium }\end{array}$} & \multicolumn{2}{|c|}{$\begin{array}{c}\text { Barriers to } \\
\text { exercises }\end{array}$} & \multicolumn{2}{|c|}{$\begin{array}{l}\text { Barriers to } \\
\text { calcium }\end{array}$} & \multicolumn{2}{|c|}{$\begin{array}{l}\text { Health } \\
\text { motivation }\end{array}$} \\
\hline & $\mathrm{F}$ & $\mathrm{P}$ & $\mathrm{F}$ & $\mathrm{P}$ & $\mathrm{F}$ & $P$ & $\mathrm{~F}$ & $\mathrm{P}$ & $\mathrm{F}$ & $\mathrm{P}$ & $\mathrm{F}$ & $\mathrm{P}$ & $\mathrm{F}$ & $P$ \\
\hline $\begin{array}{l}\text { Age at } \\
\text { menarche }\end{array}$ & 5.971 & $* 000$ & 3.679 & $* 000$ & 4.061 & $* 0000$ & 5.059 & $* 000$ & 3.021 & $* 002$ & 3.502 & $* 000$ & 4.487 & $* 000$ \\
\hline $\begin{array}{l}\text { Irregular } \\
\text { menses }\end{array}$ & 3.996 & ${ }^{*} .047$ & .257 & .613 & 39.087 & $* 0000$ & 53.695 & $* 000$ & 2.945 & .087. & 22.357 & $* 000$ & 1.217 & .271 \\
\hline $\begin{array}{l}\text { Absence of } \\
\text { menses for } \\
\text { three months }\end{array}$ & 12.316 & $* 001$ & 1.166 & .281 & 46.233 & $* 000$ & 26.109 & $* 000$ & 32.932 & $* 000$ & 27.294 & $* 000$ & 4.539 & $*_{0.34}^{*}$ \\
\hline Menopause & 7.885 & $* 005$ & .044 & .834 & 25.804 & $* .000$ & 10.149 & $* .002$ & 5.067 & $* .025$ & .490 & .485 & 4.939 & $* 027$ \\
\hline $\begin{array}{l}\text { Age at } \\
\text { menopause }\end{array}$ & 6.956 & $* 000$ & 4.067 & $* 000$ & 2.694 & $* .005$ & 3.428 & $* 000$ & 2.966 & $* 002$ & 9.102 & $* 000$ & 6.292 & $* 000$ \\
\hline
\end{tabular}

F: ANOVA Test

* Significance at $\mathrm{P} \leq 0.05$ 
Women's Health Beliefs Regarding Osteoporosis

Table (12): Relation between history of osteoporosis of the studied women and Osteoporosis Health Belief Model

\begin{tabular}{|c|c|c|c|c|c|c|c|c|c|c|c|c|c|c|}
\hline \multirow{3}{*}{$\begin{array}{l}\text { History of } \\
\text { Osteoporosis }\end{array}$} & \multicolumn{14}{|c|}{ Osteoporosis Health Belief Model } \\
\hline & \multicolumn{2}{|c|}{$\begin{array}{c}\text { Susceptibility to } \\
\text { osteoporosis }\end{array}$} & \multicolumn{2}{|c|}{$\begin{array}{c}\text { Seriousness to } \\
\text { osteoporosis }\end{array}$} & \multicolumn{2}{|c|}{$\begin{array}{c}\text { Benefits of } \\
\text { exercises }\end{array}$} & \multicolumn{2}{|c|}{$\begin{array}{l}\text { Benefits of } \\
\text { calcium }\end{array}$} & \multicolumn{2}{|c|}{$\begin{array}{c}\text { Barriers to } \\
\text { exercises }\end{array}$} & \multicolumn{2}{|c|}{$\begin{array}{c}\text { Barriers to } \\
\text { calcium }\end{array}$} & \multicolumn{2}{|c|}{$\begin{array}{c}\text { Health } \\
\text { motivation }\end{array}$} \\
\hline & $\mathrm{F}$ & $P$ & $\mathrm{~F}$ & $\mathrm{P}$ & $\mathrm{F}$ & $\mathrm{P}$ & $\mathrm{F}$ & $\mathrm{P}$ & $\mathrm{F}$ & $P$ & $\mathrm{~F}$ & $\mathrm{P}$ & $\mathrm{F}$ & $P$ \\
\hline $\begin{array}{l}\text { Family history } \\
\text { of osteoporosis }\end{array}$ & 41.707 & $* 0.000$ & 10.638 & $* 0.001$ & 6.139 & $* 0.01$ & 1.701 & 0.193 & 0.013 & 0.909 & 5.688 & ${ }^{*} 0.018$ & 1.183 & 0.278 \\
\hline $\begin{array}{l}\text { Previous } \\
\text { exposure to } \\
\text { fracture } \\
\end{array}$ & 0.087 & 0.768 & 8.154 & $* 0.005$ & 4.199 & $* 0.04$ & 0.270 & 0.604 & 0.866 & 0.353 & 0.012 & 0.912 & 1.448 & 0.230 \\
\hline $\begin{array}{l}\text { Number of time } \\
\text { of exposure to } \\
\text { fracture }\end{array}$ & \begin{tabular}{|l}
7.179 \\
\end{tabular} & $* 0.003$ & .864 & 0.433 & 4.970 & $\begin{array}{l}* 0.01 \\
\end{array}$ & 9.375 & ${ }^{*} 0.00$ & 3.780 & $* 0.036$ & 1.829 & 0.180 & 3.461 & $* 0.046$ \\
\hline
\end{tabular}

F: ANOVA Test

* Significance at $\mathrm{P} \leq 0.05$ 


\section{References}

1. Riaz M, Patel J, Tariq M, Khan M, Zuberi L, \& Abid N. Knowledge about Osteoporosis among healthy women attending a tertiary care hospital. Journal of the Pakistan Medical Association 2008; 58: 190-4.

2. Jalili Z, Nakhaee N, Askaril R, \& Sharifi $\mathrm{V}$. Knowledge, attitude and preventive Practice of women concerning osteoporosis. Iranian Journal of Public Health 2007; 36: 19-24.

3. Soleymanian A, Niknmai S, Hajizadeh E, Shojaeizadeh D, Montazeri A. Development and validation of a health belief model based instrument for measuring factors influencing exercise behaviors to prevent osteoporosis in premenopausal women (HOPE). BMC Musculoskeletal Disorders 2014; 15:61.

4. Ridout CF. Old bones in young bodies. Am Fit 1999, 17:28-31.

5. US. Department of Health and Human Services \& Centers for Disease Control and Prevention. Bone health and osteoporosis: A report of the Surgeon General, Atlanta, 2004.

6. Carlsson L, Johnson C. Osteoporosis health beliefs and practices among Korean immigrants in Nova Scotia. Journal of Immigrant Health 2004; 6(2): 93-100.

7. Egyptian Osteoporosis Prevention Society (EOPS). Overview of the Egyptian osteoporosis prevention society. Available at: http://www.iofbonehealth.org/sites/.../M E Audit-Egypt.pdf. Retrieved on: 21/1/2016.

8. Riggs B, Khosla S, Melton I. Sex steroids and the construction and conservation of the adult skeleton. Endocrine Reviews 2002; 23: 279-302.

9. Zhang Y, Xia R, Zhang B, Zhang F, Zhao $\mathrm{X}$, et al. Gender differences on osteoporosis health beliefs and related behaviors in non-academic community Chinese. Journal of Community Health 2014; 39: 545-51.

10. Deo P, Nayak R, Rajpura J. Women's attitudes and health beliefs toward osteoporosis screening in a community pharmacy. Journal of Osteoporosis 2013; volume 2013 (2013).

11. Hossien Y, Tork H, El-Sabeely A. Osteoporosis knowledge among female adolescents in Egypt. American Journal of Nursing Science 2014; 3(2): 13-7.

12. Prentice A. Diet, nutrition and the prevention of osteoporosis. Public Health Nutrition 2004; 7(1A): 227-43.

13. Malak Z. The effect of applying health belief model about osteoporosis on preventive practices among Jordanian female teachers. Unpublished Doctoral Thesis, Faculty of Nursing, Alexandria University, 2013; 47.

14. Kim K, Horan M. and Gendler P. Development and Evaluation of the Osteoporosis Health Belief Scale. Research in Nursing \& Health 1991; 14: 155-63.

15. Al Seraty W, Ali W. The Impacts of Health Belief Model Based Intervention for Osteoporosis Prevention among Female Students in Al Dawadmi Applied Medical Science, Shaqraa University, Saudi Arabia. Journal of Biology, Agriculture and Healthcare 2014; 4(7):126-3. (ISSN 2224-3208 (Paper) ISSN 2225-093X (Online)).

16. Nayak S, Roberts $M$, Chang $C$, Greenspan S. Health beliefs about osteoporosis and osteoporosis screening in older women and men. Health Education Journal 2010; 69(3): 267-76.

17. Edmonds E, Turner LW, Usdan SL. Osteoporosis knowledge, beliefs, and calcium intake of college students: Utilization of the health belief model. 
Journal of Preventive Medicine 2012; 2(1): 27-34.

18. Jeihooni A, Hidarnia A, Kaveh M, Hajizadeh E, Askari A. The survey of osteoporosis preventive behaviors in sample of iranian women: application health belief model and social cognitive theory. Indian Journal of Fundamental and Applied Life Sciences 2015; 5(S2): 56-68. ISSN: 2231- 6345

19. McLeod K. Johnson C. Review Article A Systematic Review of Osteoporosis Health Beliefs in Adult Men and Women. Journal of Osteoporosis 2011; Article ID 197454, 11 pages, doi:10.4061/2011/197454.

20. Sedlak C, Doheny M, Estok P, Zeller R, Winchell J. DXA, Health Beliefs, and Osteoporosis Prevention Behaviors. Journal of Aging and Health 2007; 19(5): 742-56.
21. National osteoporosis society. Exercise and Osteoporosis. How exercise can help with bone health, fragile bones and fractures. Available at: http://www.nos.uk/healthprofessional/s/document.doc. Retrieved on: $5 / 1 / 2016$

22. Cleveland clinic organization. The role of calcium in preventing Osteoporosis. Available at https://myclevelandclinic.org/health/dise ases-conditions/hic-Osteoporosis. Retrieved on: 5/1/2016.

23. Jalili Z, Nakhaee N, Askari R ,Sharifivi V. Knowledge, attitude and preventive practice of women concerning osteoporosis. Iranian J Public Health.2007; 2: 19-24.

24. Al-Otaibi H. Osteoporosis Health Beliefs, Knowledge and Life Habits among Women in Saudi Arabia. Open Journal of Preventive Medicine 2015; 5: 236-243. 